\title{
A szorobán értékei Magyarországon
}

\section{Mátyásné Kokovay Jolán}

Magyar Szorobán Egyesület

\begin{abstract}
Magyarországon a szorobán használatának elindításában jelentős szerepe volt Szendrei Julianna szakmai döntésének, segítségnyújtásának bátoritásának.

Neki köszönhetö, hogy 1992-töl a fövárosi tanitóképzésbe is bekerült a szorobán alkalmazásának oktatása. Az ő bizalma, féltő, óvó szeretete, folyamatos érdeklődése lendületet adott az eszköz használatának fejlesztésére, új szemléltetési módok kutatására.

Ő szorgalmazta és segítette, hogy megalakuljon a Magyar Szorobán Társaság, amely feladata a szorobánt használó tanítók összefogása.
\end{abstract}

Kulcsszavak: szorobán, matematikaoktatás, transzferhatás, japán kapcsolatok, tanterv

\section{Hogyan került a szorobán Magyarországra?}

Érdekes úton került hozzánk a japán abakusz, mert Lukács András geofizikus egy eszperantókonferencián hallott a szorobánról. Szendrei Juliannától kért szakmai véleményt, hogy a kínai számolótábla vagy a japán szorobán illeszkedik-e jobban a mi matematikaoktatásunkba. Szendrei Julianna a japán szorobánt javasolta. Így Lukács András az általa alapított Talento Iskolába meghívta tanítani az eszperantóul is beszélő japán előadót Kimie Markariant és lehetőséget adott arra, hogy az érdeklődő fővárosi iskolákban előadásokat is tartson a japán szorobántanár. Ő a pedagógusoknak szóló előadására egy 1 . osztály részvételét kérte. Meghatározó élményt jelentett számunkra, hogy az előadása végén kipróbálhattuk az eszközöket és láttuk, hogy a gyerekek azonnal szakaszerüen és nagyon szívesen számoltak vele, mi felnőttek még csak próbáltunk eligazodni a sok golyó között.

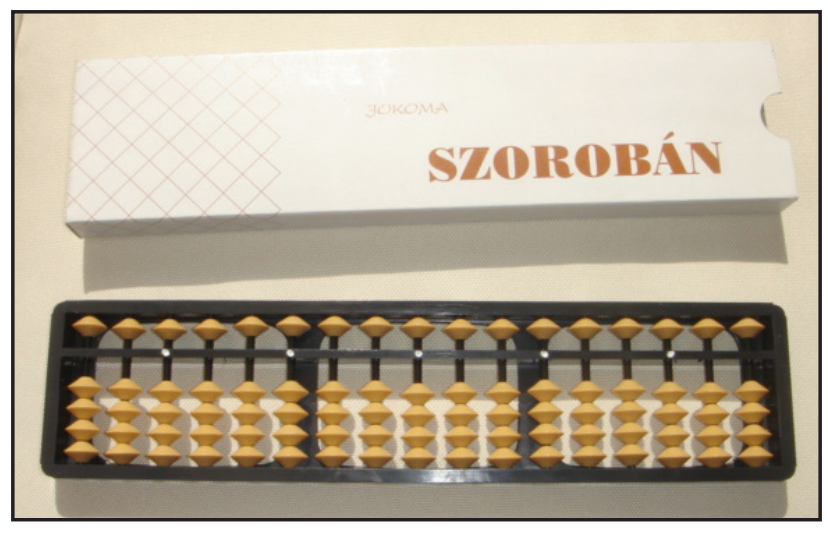

1. ábra: Szorobán 


\section{A szorobán bemutatása}

A japán szorobán évszázadok alatt alakult ki a kínai szuan-panból, amit magyarul számolótáblának nevezünk.

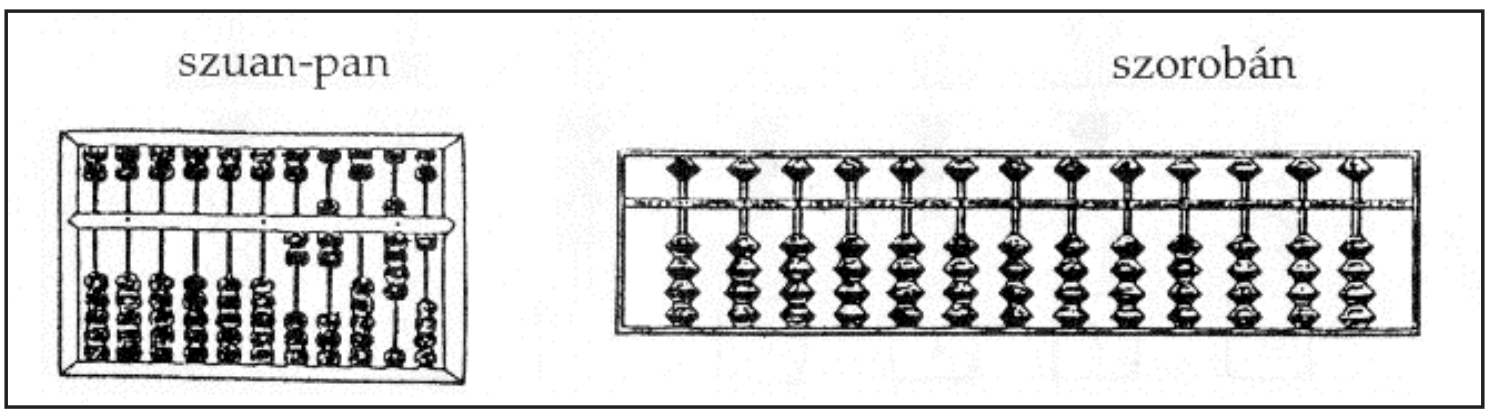

2. ábra: A szuan-pan és a szorobán

A tízes számrendszerre épülő, helyiérték-táblázathoz hasonlító eszköz használata könnyen megérthető, mert a pénzváltás logikájával müködtethető. A különböző oszlopszámú eszközön az értékléchez érintett golyókkal számolunk. Ez a keresztülfutó léc osztja két részre az eszközt. Itt az alsó négy sorban minden golyó egyet, a felső sorban levők mindegyike pedig ötöt ér a saját helyi értékén. (Mátyásné, 1999)
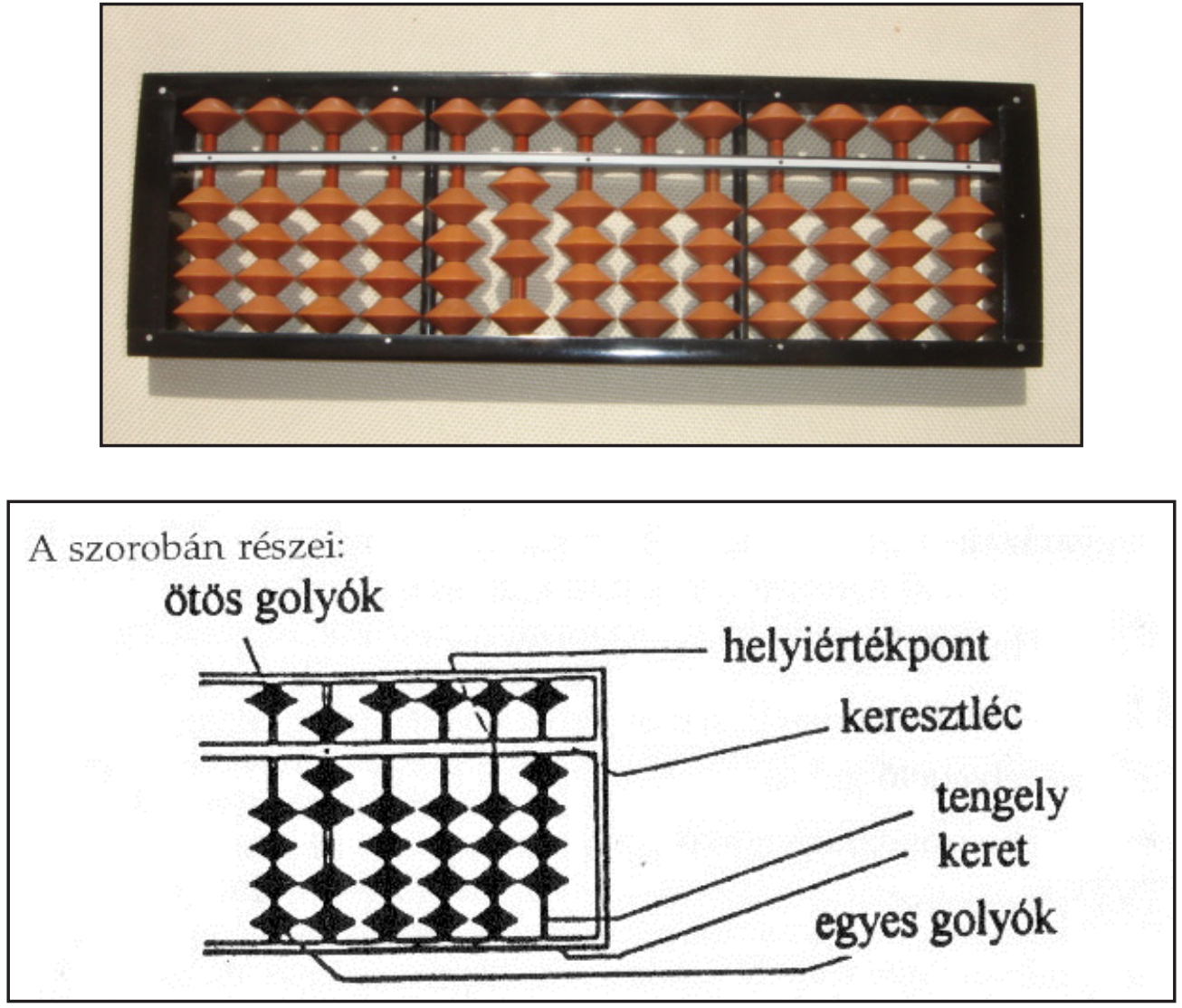

3. ábra: A szorobán részei 


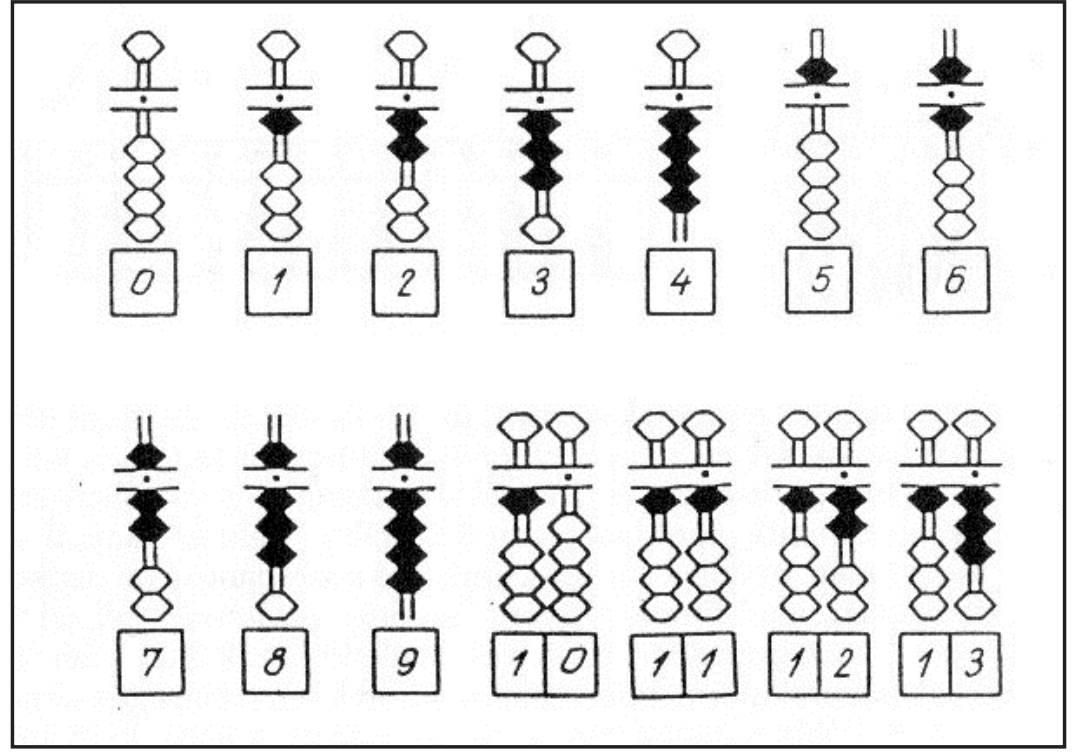

4. ábra: Számképek a szorobánon:

Általában a jobb kéz mutató-, és hüvelykujjaival mozgatjuk a golyókat, bal kézzel pedig átfogjuk a keretet és a számoszlopon vezetjük a szorobánt. Tehát munka közben mindkét kezünket használjuk. Balkezesek az író kezükkel mozgatják a golyókat (lásd: alábbi kép).
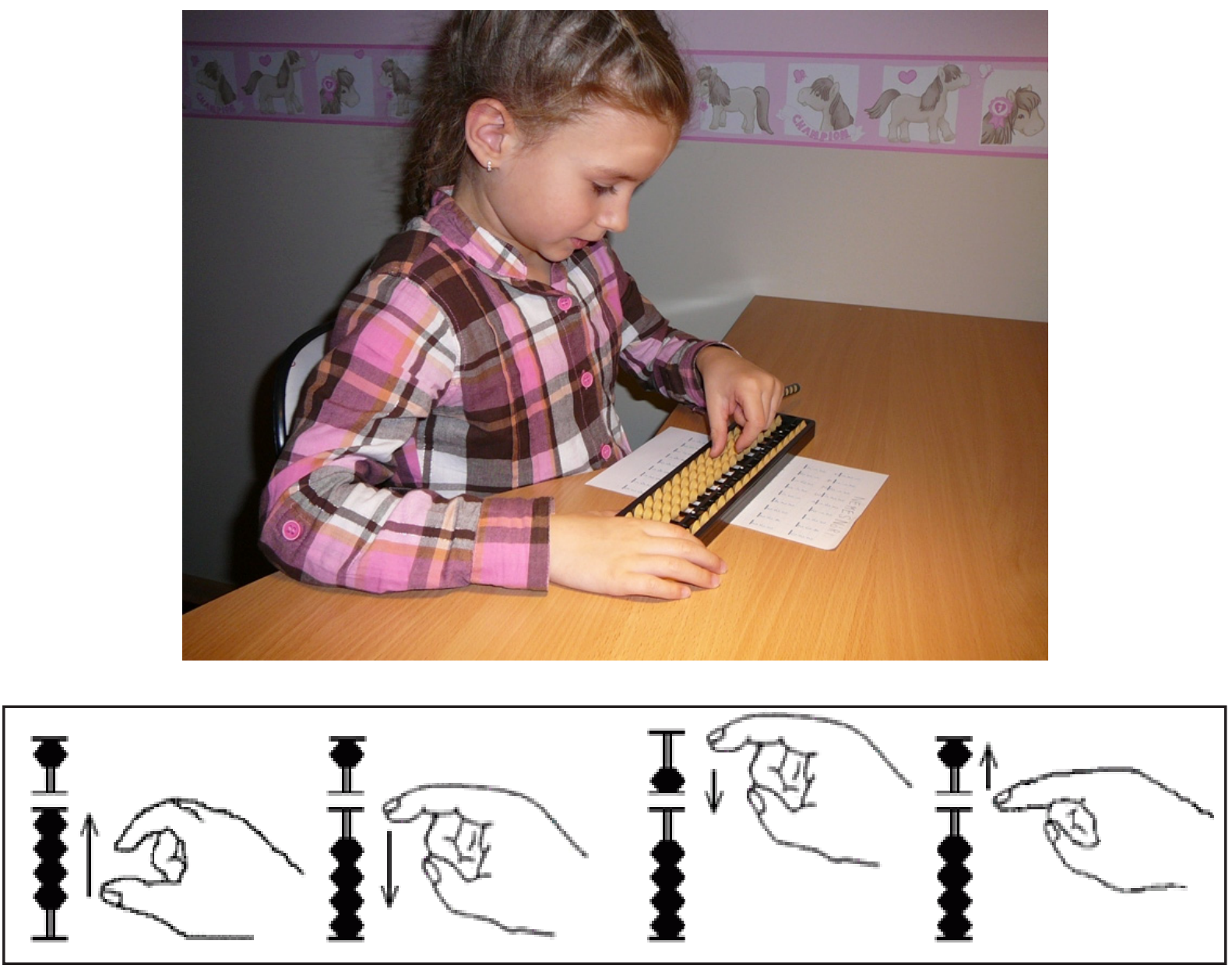

5. ábra: Ujjmozgások szabályai 
A helyiértékes tájékozódást a keresztlécen található pontok segítik. PI.: ha szeretnénk kirakni a 32-t, akkor a tízeseknél felhúzunk 3 golyót és tőle jobbra az egyesek oszlopában 2 golyót. Ilyenkor tapasztalják a kicsik, hogy a 32 áll 3 db tízesből és $2 \mathrm{db}$ egyesböl.

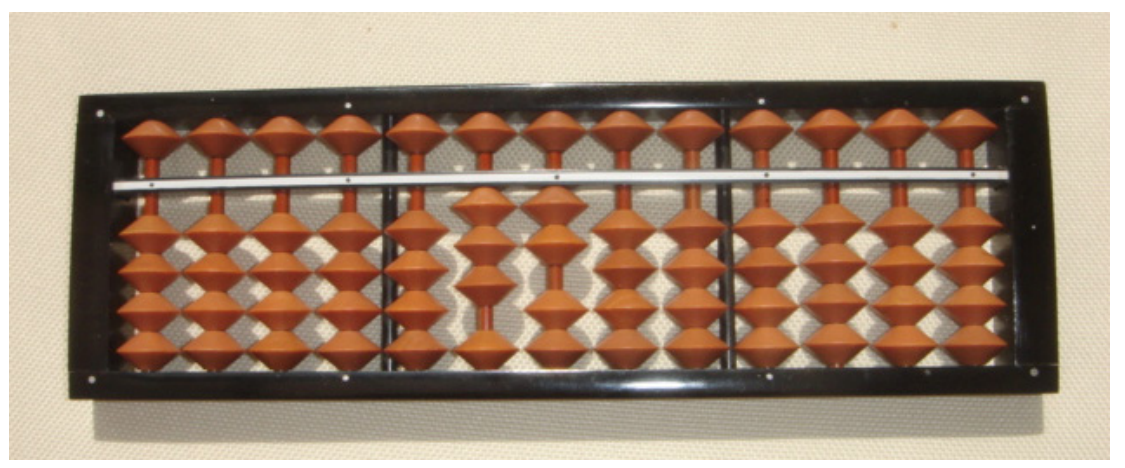

\begin{tabular}{|c|c|c|c|}
\hline 1000 & 100 & 10 & 1 \\
\hline$E$ & $S Z$ & $T$ & $E$ \\
\hline & & 3 & 2 \\
\hline & 3 & 2 & 4 \\
\hline & & & \\
$y$ & $=324$ \\
&
\end{tabular}

$30+2=32$

$300+20+4=324$

6. ábra: Számolás a szorobánnal

Ahhoz, hogy a hallott számot a szorobánon meg tudjuk jeleníteni, minden esetben tudni kell az adott szám helyi érték szerinti bontását.

Mi - a japánoktól eltérően - az egyeseket a középső helyiérték-ponthoz helyezzük, hogy a kicsik tapasztalhassák, hogy a törtszámokból is nagyon sok lesz.

Arra törekszünk, hogy a gyerekek soha ne érezzék fárasztónak, unalmasnak a szorobán használatát, ezért úgy vezettük be, hogy minden matematikaórán csak 5-10 percet használhatják a tananyag megértéséhez, gyakorlásához. Nincs hozzá külön követelmény, sem tankönyv, sem házi feladat. (Ebben az összes, abakuszt használó országtól eltérünk, mert mindenütt adnak otthoni gyakorlásra külön feladatokat.)

A szorobán minkét agyféltekét fejleszti, mert számolás közben több érzékszervünket is használjuk egyszerre.(Czeizel, 1984). Mivel az írást is kiváltja, ezért a kicsik lényegesen gyorsabban tudnak számolni vele. Különösen nagy segítséget jelent azoknak a tanulóknak, akik számára az új ismeretek elsajátításakor az érzékszervek közül a tapintás fontosabb, mint a látás vagy a hallás. A gyerekeket örömmel tölti el, hogy a számfeladatok megoldása során rövid idő alatt sok jó eredményt érnek el. Ez a sikerélmény további erőt ad nekik a gyakorlásra.

\section{A szorobán szerepe a matematikaoktatásában}

\subsection{Tantervi követelmények teljesítése}

Japánban a szorobán használatával a minél gyorsabb, minél nagyobb számokkal fejben történő számolás elérése a cél. Nálunk a matematika tanításában a sokoldalú 
szemléltetést és a tantárgy megkedveltetését tüztük ki célul. Ehhez folyamatosan kutatjuk a lehetőségeket (Szendrei, 2005).

A számfogalom kialakítása és erősítése mellett a bontások szemléltetéséhez, a mértékváltások gyakorlásához és a logikus gondolkodás fejlesztéséhez találtunk új felhasználási módokat. A gondolkodtató feladatok megoldásával a divergens gondolkodást és ezek alkotásával a kreativitást fejlesztjük.

Mértékváltás segítése szorobánnal $\mathrm{PI} .123 \mathrm{~cm}=1 \mathrm{~m}+23 \mathrm{~cm}$ vagy $123 \mathrm{~cm}=$ $12 \mathrm{dm}+3 \mathrm{~cm}$ stb...

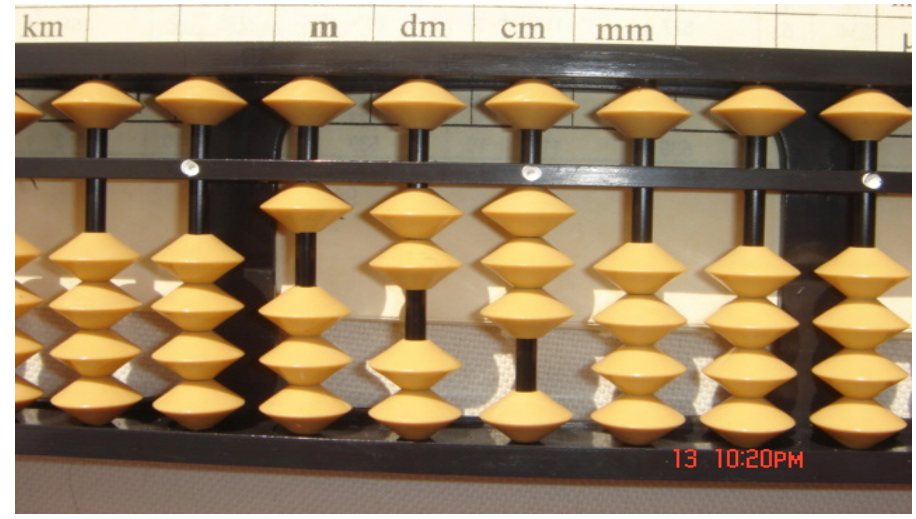

\begin{tabular}{|c|c|c|c|c|c|c|}
\hline $\mathrm{km}$ & & & $\mathrm{m}$ & $\mathrm{dm}$ & $\mathrm{cm}$ & $\mathrm{mm}$ \\
\hline & $\mathrm{hl}$ & & $\mathrm{l}$ & $\mathrm{dl}$ & $\mathrm{cl}$ & $\mathrm{ml}$ \\
\hline $\mathrm{kg}$ & & $\mathrm{dkg}$ & $\mathrm{g}$ & & & \\
\hline
\end{tabular}

7. ábra. Mértékváltást segítő szalag

Az egyes matematikai fogalmak kialakulását megelőzik a szorobán használata közben szerzett tapasztalatok. Például az elsősök tapasztalják, hogy ha egy számhoz hozzá kell adni valamennyit, akkor a golyókat hozzátolom az értéklécnél levőkhöz, ha pedig el kell venni valamennyit, akkor a golyókat elhúzom. Közben tapasztalják, hogy hozzáadásnál több lesz, elvételnél kevesebb marad.

A matematika tantárgyra vonatkozó továbbhaladás feltételeit eddig minden szorobánt használó 1-4. osztályos tanulónak sikerült teljesíteni. Ez az oktatásban nagy hangsúllyal szereplő Számtan, számelmélet, algebra témakör tananyagának tanításához használt taneszközök megkedveltetésének is köszönhetö. A számfogalom alakítása, erősítése, az alapműveletek tanítása, gyakorlása, a nyitott mondatok, szöveges feladatok megoldása során segítségül hívható a szorobán.

A helyi tantervi követelmények teljesítésében a négy alapmüvelet elsajátítása rövidebb idő alatt eredményesebben történik szorobánnal, így sokkal több idő marad a geometria, valószínüség, statisztika témaköreinek tanítására. (II. Helyi tanterv 2013. Kimle, Nemzetiségi Általános Iskola)

A különböző országos szintű matematikaversenyek legjobbjai a szorobánt használó tanulók közül kerülnek ki.

\subsection{Miért kedvelik a gyerekek?}

A tanulók szívesen használják a szorobánt, mert sikerélményt, biztonságérzetet ad számukra. 
Úgy érzik, hogy csak játszanak a szorobánnal, miközben sok számfeladatot gondolkodva, figyelmesen és fegyelmezetten oldanak meg. Örömet jelent a számukra, hogy a fárasztó és lassú írás helyett csak a golyókat kell mozgatni ahhoz, hogy sok hibátlan megoldásuk legyen (Radnainé et. al, 1994).

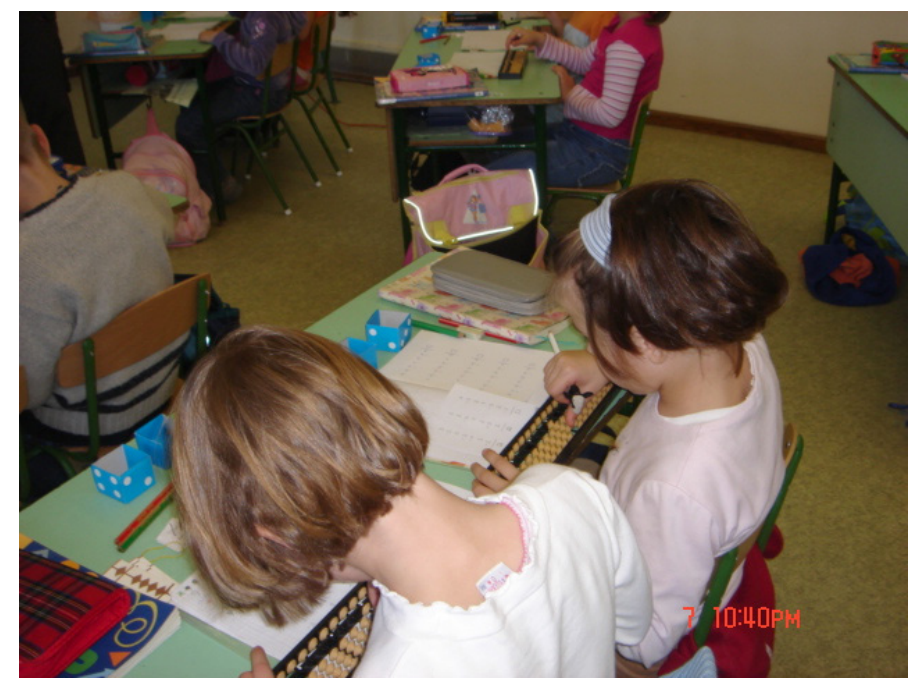

8. ábra: 1. osztályosok matematikaórán

Mivel csak 5-10 percet használják a gyerekek a szorobánt, ezért nem fáradnak el és nem unják meg. Így érjük el, hogy hosszú éveken keresztül ébren tudjuk tartani az érdeklődésüket, lelkesedésüket, ezért mindig szívesen oldanak meg egyre nehezebb és több feladatot. A tanulók számára örömöt jelenthet az is, hogy ök valami olyan ismerettel rendelkeznek, amit az okos felnöttek közül sokan nem ismernek. Ez is motiválhatja őket arra, hogy részt vegyenek délutáni szakkörökön.

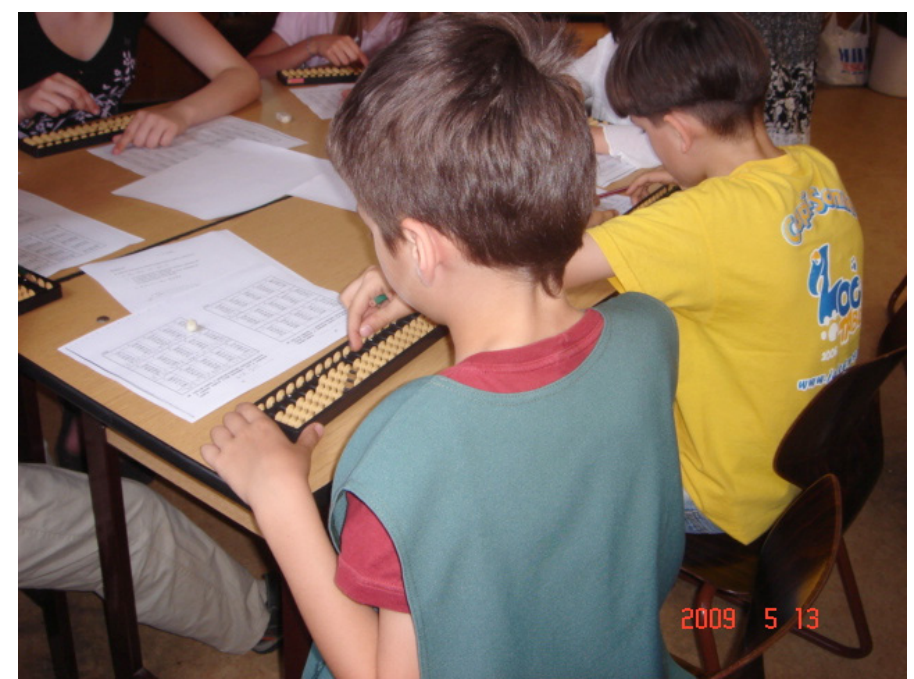

9. ábra: Szorobánszakkörön

Az ellenőrzés tapintatos módját a japánoktól vettük át. A visszajelzés formája szerint a diktált láncszámolás után közösen bemondják az eredményt. A hallottakból kiderül, hogy a következő feladatsort gyorsabban lehet-e diktálni vagy esetleg nehezebb feladatsor következhet. A gyerekek hibájuk esetén hallják, hogy az ő eredményük eltér a többitöl, de a másodperceken belül a következő feladatnál igyekeznek 
sokkal jobban figyelni. Hibás megoldás esetén nem szégyenülnek meg a társaik előtt. A kórusban bemondott eredmény őszinteségre szoktatja őket és nem kell aggódniuk semmiféle elmarasztalástól. Itt az ellenőrzésnél nem alkalmazzuk az egyébként gyakran használt „tettenérő” számonkérést, pl.: Tegye fel a kezét, akinek egy hibája van, tegye fel a kezét, akinek két hibája van stb. A tanár-diák között a visszacsatolás azonnali és a gyakorlás közben szabad téveszteni (Radnainé et al, 1994).

Ha a tanulók úgy érzik, hogy már fejben is képesek megoldani a feladatot, akkor önállóan dönthetnek arról, hogy eszköz nélkül számoljanak. Ez a bizalom az önértékelésüket is fejleszti.

\subsection{Hogyan segíti a pedagógusok munkáját?}

Nincs szükség külön motivációra (Mérei-Binét, 2003) még az unalmasnak tűnő számfeladatok gyakorlásánál sem, mert az eszköz használata sikerélményt nyújt a tanulóknak, ezért a lassabban haladók is szívesen dolgoznak vele. Itt nem leírjuk, hanem kirakjuk a számokat és így minimálisra csökken a leírható számjegyek száma, ezért rövidebb idő alatt több feladat oldható meg és még javítani sem kell. Mivel a négy alapmüveletet lényegesen kevesebb idő alatt eredményesebben tudják tanítani, ezért sok idő felszabadul. Ezt kihasználva például több időt fordíthatnak a számjegyek írásának gyakorlására vagy a problémák matematikai szakkifejezésekkel történő megfogalmazására. Jó szokásokat lehet kialakítani a tanulóknál, amikor egy bonyolultabb szövegezésű gondolkodtató feladatnál - a máskor az olvasást vagy gondolkodást elhárító tanulók is - szívesen próbálkoznak a helyes megoldások keresésével. PI.: 2. osztályos feladat: „Olyan 50-nél nagyobb, 7 golyóval kirakható kétjegyü számokat keresünk, amelyekben a tízesek és az egyesek száma között 3 a különbség $(69,74.96)$.” 3. osztályos feladat: „Olyan 380-nál nagyobb, 540-nél kisebb, 7 golyóval kirakható számokat keresünk, amelyek oszthatók maradék nélkül 3-mal (456, 465, 519, 528, 537)."

A matematikaórán könnyen szervezhető munkaformákat is alkalmazhatnak, például frontális, egyéni vagy páros munkát.

A pedagógusoknak könnyebb a munkájuk a fegyelmezetten, csendben dolgozó elégedett tanulókkal. Amíg szorobánnal számolnak, csend, béke, nyugalom van az osztályban, amire nagy szükségük van a tanulóknak is, hogy megtapasztalják, milyen jó dolog a saját munkájukra koncentrálni és elmélyülten, figyelmesen dolgozni.

\section{A szorobán alkalmazásának transzferhatása az egyéb tantárgyak tanulására}

Minden tantárgy tanulásánál fontos, hogy a tanulók figyelmesen, fegyelmezetten, az adott feladatra koncentrálva, pontosan dolgozzanak (Mérei-Binét, 2003) A várható sikerélmény elérése érdekében a szorobán használatánál az ilyen munkavégzést gyakorolhatják és sajátíthatják el. A helyes eredmény elérése érdekében a golyókat a szabályoknak megfelelően kell mozgatniuk. Mindezt belső indíttatásból teszik a máskor figyelmetlen, fegyelmezetlen tanulók is, mert tapasztalták, hogy nekik is sikerülhet hibátlanul számolni.

A 6-10 éves korosztálynál különböző automatizmusokat alakítunk ki, melyek hosszú évekre meghatározóak a számukra. Az olvasás, írás, számolás mellett ilyen például a jól végzett munka után érzett öröm vagy a folyamatos önellenörzés kialakítása (F. Várkonyi, 2013). 
Mivel a hüvelyk- és mutatóujj használható a golyók mozgatásához, így közben a finommozgások is fejlődnek. A finommotorika fejlesztése fontos például az írás tanításánál is.

A szorobán használatát általában ujjgyakorlatokkal kezdjük. Ennél a látás, hallás, ujjmozgás, beszéd együttes használatával oldják meg a feladatokat.

A formaemlékezet megfelelő fejlettségi szintje szükséges például az olvasás, írás és az idegen nyelvek tanulásánál.

A fejben történő számolás gyakorlásánál a maguk elé képzelt szorobánon számolva oldják meg a feladatsorokat. Mielőtt az elvont eszközt maguk elé képzelik, könynyítésként egy jól ismert tárgyat kell maguk elé képzelniük. A konkrét gondolkodású 6-10 éveseknek például kezdetben a legkedvesebb játékukat kell felidézni. Ha a tanuló ezt képes könnyen, gyorsan elképzelni, akkor a gyakorlás után könnyebb lesz egy idegen nyelven tanult kifejezést is felidéznie.

A vizualizáció gyakorlása és a vizuális memória fejlesztése hozzájárul a többi tantárgy sikeresebb tanulásához, a kreativitás fejlesztéséhez.

\section{További tervek, japán kapcsolataink}

Célul tủztük ki, hogy a leendő és fiatal tanítókat jobban bátorítjuk az eszköz használatára, fokozottabban bekapcsoljuk őket a kyúvizsgák és hazai szorobánversenyek lebonyolításába, mert a 90-es évek elején föleg a tapasztalt tanítók kezdték használni a szorobánt. Szeretnénk meggyőzni a felső tagozatban matematikát tanítókat is, hogy számukra is sok segítséget jelent az eszköz használata. A Magyar Szorobán Társaság tagjai továbbra is tartanak bemutatóórákat és vállalják az érdeklődő végzős és leendő hallgatók szakmai felkészítését és segítését. Az ELTE TÓK Matematika Tanszéke évtizedek óta minden szemeszterben sok hallgató számára teszi lehetővé, hogy szabadon választható kurzus keretében elsajátítsa a szorobánnal való számolási tevékenységet.

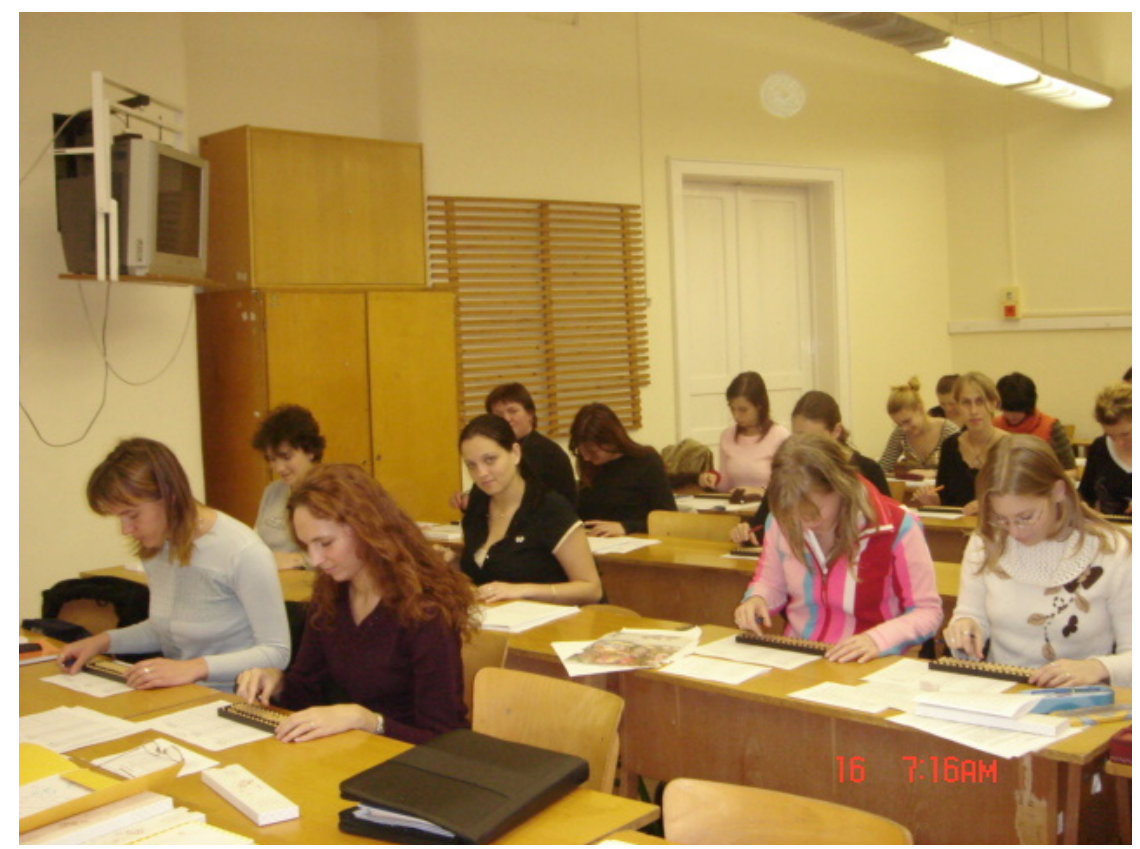

10. ábra: Szorobánfakultáció, ELTE TÓK 


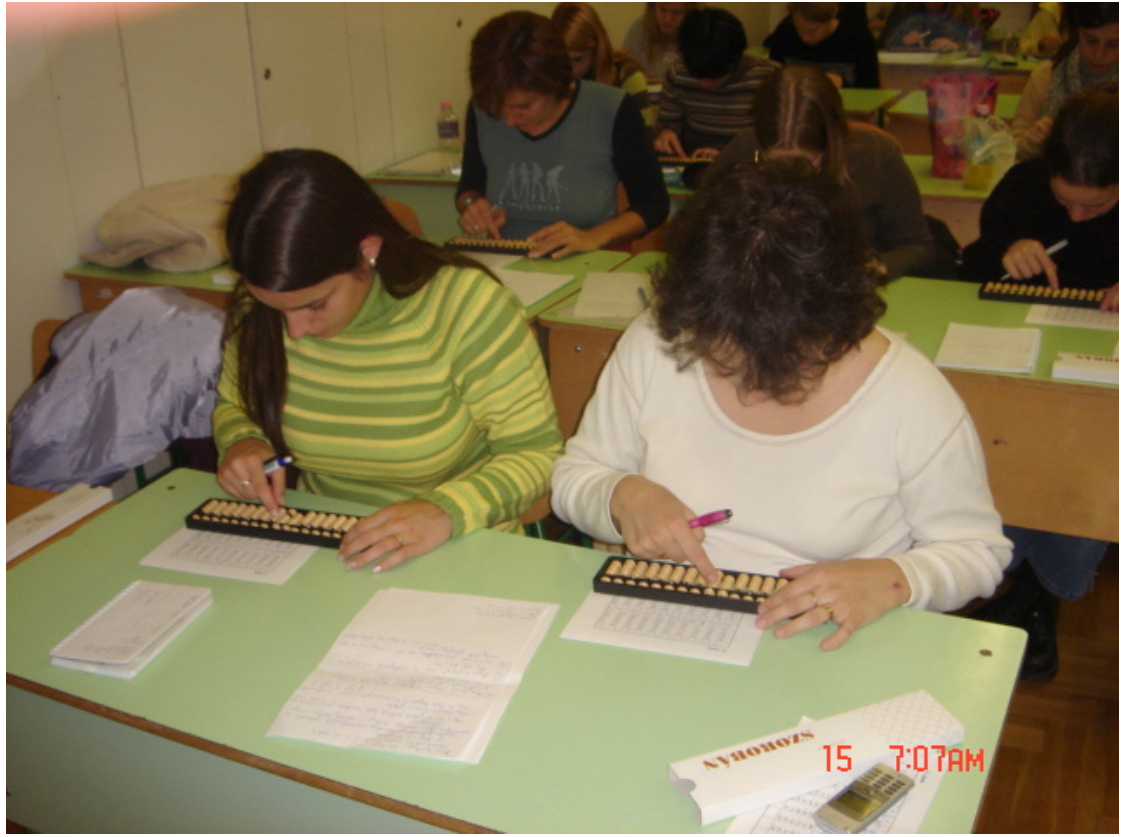

11. ábra: Szabályos eszközhasználat, ELTE TÓK

A Japán Szorobánoktató Szövetséggel 1997-től tartjuk a kapcsolatot. A kyúvizsgákhoz ők küldik a feladatokat és a sikeresen vizsgázott tanulóknak a japán okleveleket. Ezt évente 900-1000 fő veheti át. A különböző szintű vizsgák mellett versenyeket is szervezünk. A területi versenyek győztesei az országos szorobánversenyen mérhetik össze tudásukat. Évente 400 fő méretteti meg magát.

Folyamatos kapcsolatot tartunk az Kelet-osakai Szorobán Szövetség elnökével Suzuki Iwao Úrral, aki három alkalommal látogatott el hozzánk. Az utóbbi két alkalommal több szorobántanár is elkísérte, hogy részt vegyenek az országos szorobánversenyeinken, konferenciánkon, bemutató óráinkon.

Hálásak vagyunk a tőle kapott eredeti szorobánokért és a sok szakmai kiadványért, valamint vizuális anyagokért.

Az ő kitartó, rendszeres szakmai érdeklődése munkánk iránt mindig új lendületet ad számunkra. Talán ő az, aki - bár nem ismerte Szendrei Juliannát - mégis mintha egy kicsit pótolni szeretné számunkra.

\section{Irodalom}

Czeizel Endre (1984): Az érték bennünk van. Gondolat Kiadó, Budapest.

Domján Károly (1974): Oksági összefüggések megértése 6-10 éves korban. Akadémiai Kiadó, Budapest.

F. Várkonyi Zsuzsa (2013): Már 100x megmondtam. Háttér Kiadó, Budapest.

Mátyásné Kokovay Jolán (1999): Feladatgyüjtemény 1-3. szint. Jokoma Kft, Budapest.

Mérei Ferenc-V. Binet Ágnes (2003): Gyermeklélektan. Medicina Könyvkiadó, Budapest.

Osmanné Sági Judit - Erdélyi Alisza (1982): Mi a neuropszichológia? Magvető Kiadó, Budapest.

Piaget J. (1993): Az értelem pszichológiája. Gondolat Kiadó, Budapest.

Radnainé dr. Szendrei Julianna, Makara Ágnes, Mátyásné Kokovay Jolán, Pálfy Sándor (1994): Tanulási nehézségek a matematikában. IFA-BTF-MKM

(Tanítók kiskönyvtára 6.), Budapest.

Selye János (1973): Életünk és a stress. Akadémiai Kiadó, Budapest.

Szabó László Tamás (1988): A „rejtett tanterv”. Magvető Kiadó, Budapest.

Szendrei Julianna (2005): Gondolod, hogy egyre megy? Typotex Elektronikus Kiadó, Budapest. II. Helyi tanterv (2013): (10.2.) Kimle, Nemzetiségi Általános Iskola. 